\title{
Article \\ Exploring the Traveler's Intentions to Use Public Transport during the COVID-19 Pandemic While Complying with Precautionary Measures
}

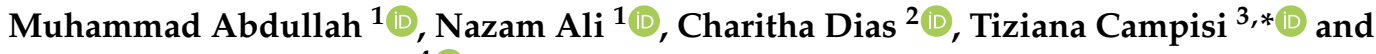 \\ Muhammad Ashraf Javid ${ }^{4}$ (D) \\ 1 Department of Civil Engineering, School of Engineering, University of Management and Technology, \\ Lahore 54782, Pakistan; muhammadabdullah@umt.edu.pk (M.A.); nazam.ali@umt.edu.pk (N.A.) \\ 2 Qatar Transportation and Traffic Safety Center, College of Engineering, Qatar University, Doha P.O. Box 2713, \\ Qatar; cdias@qu.edu.qa \\ 3 Faculty of Engineering and Architecture, University of Enna Kore, Cittadella Universitaria, 94100 Enna, Italy \\ 4 Department of Civil and Environmental Engineering, University of Nizwa, Birkat-al-Mouz, Nizwa 616, \\ Oman; muhammad.javid@unizwa.edu.om \\ * Correspondence: tiziana.campisi@unikore.it
}

Citation: Abdullah, M.; Ali, N.; Dias, C.; Campisi, T.; Javid, M.A. Exploring the Traveler's Intentions to Use Public Transport during the COVID-19 Pandemic While Complying with Precautionary Measures. Appl. Sci. 2021, 11, 3630. https://doi.org/10.3390/app11083630

Academic Editor: Giorgio Biasiol

Received: 18 March 2021

Accepted: 14 April 2021

Published: 17 April 2021

Publisher's Note: MDPI stays neutral with regard to jurisdictional claims in published maps and institutional affiliations.

Copyright: (c) 2021 by the authors. Licensee MDPI, Basel, Switzerland. This article is an open access article distributed under the terms and conditions of the Creative Commons Attribution (CC BY) license (https:/ / creativecommons.org/licenses/by/ $4.0 /)$.

\begin{abstract}
Public transport use has drastically declined during the COVID-19 pandemic because the virus spreads through close contact with infected people and contaminated surfaces, especially in closed-environments. Evidence suggests that following the necessary safety guidelines can limit the spread of the virus, however, non-compliance to precautionary measures has been reported widely. Ignoring the precautionary measures may lead to quick transmission of the virus since public transport vehicles generally resemble closed-environments. This study explores people's intentions to use public transport during the COVID-19 pandemic while adhering to precautionary measures. For this purpose, a total of 1516 useable responses were collected through a questionnaire survey conducted in Lahore, Pakistan. Regression models were developed to model the intentions to use public transport during the pandemic, to adhere to the precautionary measures while using public transport during the pandemic, and to use public transport while suffering from COVID-19 disease. The results of this study will help in understanding the intentions of the public transport users during the COVID-19 pandemic. It will also provide insights for policymakers and public transport operators about further necessary actions to promote safe public transport use during the current and any possible future pandemics. As public transport use declined during the pandemic, policy implications for alternative mobility options such as demand-responsive-transport (DRT) are also presented. Considering the study results, a policy interventions framework is proposed to promote the safe use of various public transport modes, particularly in developing regions.
\end{abstract}

Keywords: COVID-19; public transport; traveler intention; ordinal regression; pandemic

\section{Introduction}

The outbreak of COVID-19 (a disease caused by the novel coronavirus), which started in December of 2019 and spread rapidly around the globe, has severely affected public transport because it spreads through close contact, especially inside confined environments. The World Health Organization (WHO) declared this disease as a global pandemic in March 2020 [1]. At present (10 March 2021), a total of 116,874,912 people has been affected by this disease with 2,597,381 deaths [1]. In Pakistan, confirmed cases of COVID-19 are 595,239 and 13,324 people have died as of 10 March 2021 [2]. Governments around the world have taken certain measures to prevent the spread of the deadly virus including closure of educational institutions, non-essential businesses, restaurants, bars and preventing social gatherings [3]. Several governments around the world imposed lockdowns to restrict the movement of people. The government of Pakistan also imposed the first lockdown on 1 
April 2020 which was eased in different phases, followed by a series of smart lockdowns in areas containing big infection clusters [2].

Many countries have started to lift the lockdowns or ease the movement restrictions owing to the reduced number of infections or financial concerns. Hence, the transport sector has also started to resume its operations, however, it is believed that the use of public transport might accelerate the infection rate due to its disagreement with the social-distancing requirements [4]. Previous studies also reported that the spread of influenza epidemic accelerated through a subway [5]. Similarly, a strong association and infection of Acute Respiratory Infection (ARI) and Tuberculosis (TB) was found among the frequent users of public transport as compared to those who do not frequently use public transport [6-8]. Since the use of public transport might accelerate the infection rate of COVID-19 among its users, promoting the frequent use of public transport might require some special attention in the post-COVID-19 era and responsible behavior from its users [9]. The spread of the virus can be reduced by strictly following the guidelines of World Health Organization (WHO) such as wearing a face mask, maintaining social distance, and using disinfectants to clean hands and surfaces [10-13]. Non-compliance to necessary guidelines and instructions may lead to rapid transmission of COVID-19 especially inside closed environments such as public transport $[10,14,15]$. In addition, it is also argued that maintaining a social distance of 2-m (6-ft) is not possible while using public transport especially in populated countries [16].

In addition to evaluating mode choices and travel patterns, it is essential to disseminate studies on sustainable and resilient mobility, i.e., mobility that can respond positively or at least mitigate the critical aspects of future catastrophic or pandemic events [17] Furthermore, various studies confirm the need to analyze the emotional impact that the pandemic has had on public transport users in order to understand which feelings such as anxiety, fear or stress may derive from the use of public transport or may reduce the propensity to do so $[18,19]$. The study of mental health and psycho-social barriers for different types of users is essential for the improvement of public transport services [20] and shared mobility [21]. The emotional aspect is in fact strongly connected to the definition of the human factor and therefore has repercussions on the human-environment, humanvehicle and human-human interactions. Public transport remains to be a necessity even during the pandemic as a majority of the population in developing countries, particularly essential workers, e.g., healthcare staff and other emergency service staff, still depend on public transport. Therefore, regaining ridership is important in the post-Covid-19 era, as declined demand for public transport could cause an increase in car-ownership which could lead to other issues like congestion and pollution. On the other hand, public transport operators might decrease the service frequency due to the reduction in demand and profits. As explained in [22], 18\% of households that did not own cars in the Boston area expected to buy cars mainly because of the uncertainty in the service frequency of public transport services, lack of trust in safety measures followed by the operators, and other passengers. Therefore, this study aims at exploring people's intentions to use public transport during the COVID-19 pandemic. The study had the following three main objectives:

1. To model the intentions to use public transport during the COVID-19 pandemic

2. To model the intentions to adhere to safety precautions while using public transport during the COVID-19 pandemic

3. To model the intentions to use public transport during the pandemic while experiencing COVID-19 symptoms

A questionnaire was designed and administered to collect the required data in Lahore, Pakistan. Three different regression models were then developed to achieve the objectives of this study i.e., to model the people's intentions to use public transport, to adhere to necessary instructions while using public transport, and to use public transport while having COVID-19 symptoms. Appropriate statistical analyses and the corresponding results are presented along with the policy implications for more responsible and safe public transport in the post-COVID-19 world. 
The rest of the paper is organized in the following manner: Section 2 discusses the relevant literature studies, Section 3 describes the methods and materials for carrying out this research work, Section 4 highlights the main findings of the research study. Finally, Section 5 summarizes the results and proposes new policy options for safer mobility options.

\section{Literature Review}

In order to control the spread of the infections or to 'flatten the curve', travel restrictions of different degrees have been adopted by different countries during different stages of the pandemics $[5,8,23]$. As highlighted in recent studies, owing to the reason that the virus spreads mainly through close contact with an infected person, public transport could largely contribute to the spread of infectious diseases [13,15,24-29]. Therefore, passengers are required to follow protective and preventive measures, such as, wearing face masks, and maintaining social distancing while using and waiting for public transport [25]. As explained in [30], physical distancing of more than $1 \mathrm{~m}$, use of face masks, and eye protection have been identified as the most effective preventive measure to reduce the person-to-person transmission of COVID-19. In addition, personnel management and protection, cleaning and disinfection of the surrounding environment, and health education have also been identified as the comprehensive measures to control the spread of Covid-19, particularly when using public transportation [31]. Public transport operators could also play a role to minimize the risk of infection by offering flexible or more frequent services to satisfy user needs while reducing congestion and thereby ensuring social distancing, providing sanitizers, automated opening of doors, ensuring adequate ventilation [3,12,14]. A simulation-based study, which used automatic passenger count data in the Minneapolis area in the US, explained that to reduce the risk of disease transmission, the number of passengers inside a bus should be limited to 15 [32]. However, to allow a reasonable waiting time for passengers due to the reduced capacity, the frequency of the service should be increased. In addition to public transport operators, workplaces could also assist to reduce or distribute the passenger volumes in public transport modes (to facilitate social distancing measures) by offering to work from home options and flexible or staggered working hours for the staff [33]. However, it is not guaranteed that the passengers always follow these guidelines stipulated by the governments. For example, as explained by [15], although a majority of buses adhere to the social distancing guidelines, the instructions on using face masks were not completely followed. Thus, in general, the use of public transport modes is discouraged during pandemics [34]. Recent studies based on mobility data and passenger or ticket counts explained that there was a dramatic reduction in public transport use in many countries. For example, public transport users declined by up to $93 \%$ in Spain [35], 60\% in Sweden [36], 80\% in Hungary [37], and 77\% in Poland [38]. On the other hand, people limit travelling, particularly by using public transport modes, owing to the perceived fear of infection $[39,40]$. Past studies have highlighted that, as perceived by the people, avoiding public transport was one of the most effective precautionary measures to avoid infectious diseases [41]. Globally, a substantial reduction in the use of public transport was observed $[17,42]$. A study based on travel diaries and a questionnaire survey conducted in the Netherlands reported that trips that used public transport dropped by more than $90 \%$. This decline was expected because the government as well as public transport operators advised people to use it only when it is extremely necessary [43]. Another questionnaire survey conducted globally stated that the mode share for public transport declined from 36\% before Covid-19 to $13 \%$ during Covid-19 [42]. This study further explained that the pandemic-related underlying factors, such as infection concern, social distancing, cleanliness, passengers with face masks, were significant predictors of mode choice during Covid-19. Ref. [4] explored the preference between private and public transport mode preference of Indian commuters. The findings of this study indicated that, during the transition to lockdown phase, only 5.3\% of respondents shifted from public to private modes while a majority (approximately 51\%) did not change their travelling mode. Further, they explained that the commuters perceived less importance on safety while 
choosing a mode. These finding highlights the importance of considering the available alternative travel modes during pandemics. A survey that was conducted in Australia concluded that approximately $58 \%$ of respondents were concerned about hygiene when using public transport during the pandemic compared to only $5 \%$ who concerned about hygiene on normal days [44]. This observation highlights the importance of cleanliness and hygiene when resuming the services. A recent study conducted in Poland revealed that $90 \%$ of respondents stopped or limited the use of public transport during the Covid19 pandemic [45]. Although a majority $(75 \%)$ of the respondents mentioned that they will use public transport again once the pandemic is over, the rest $(25 \%)$ has entirely lost interest in public transport as they doubted that the services will ever be safe. This observation highlights that it is extremely important to maintain safety and comfort during the pandemic as the choice of public transport in the future will largely depend on the perceived safety.

On the one hand public transport use declined, whereas on the other hand, the modal share of private transport and active modes, in general, increased around the world. For example, the modal share of private car increased from $48 \%$ to $77 \%$ and $43 \%$ to $65 \%$ due to the pandemic in Spain and Budapest, respectively [35,37]. A global survey reported that car use increased from $32 \%$ to $39 \%$ due to the pandemic [42]. The study also reported an increase of about $7 \%$ in walking during the pandemic.

In addition, knowledge and awareness about the pandemic and prevention measures may help in containing the virus transmission [46]. A nationwide study conducted in the United States reported that the lack of awareness about the prevention methods may increase the risk of the virus transmission in certain racial and ethnic communities [47]. However, empirical evidence also suggests that increased awareness about prevention measures may not necessarily increase compliance to the safety precautions, which may possibly be linked to low perceived risk of the COVID-19 pandemic [48]. Hence, awareness about both the risk of the disease as well as the prevention measures is necessary to contain the virus especially inside public transport.

To resume public transport services in the post-Covid-19 era, regaining the attraction is crucial. A recent study highlighted that new policies, e.g., "fare-free policy", "more rides-more discounts", "off-peak-hours free-ride policies", could enhance the ridership [49]. This study concluded that the latter 2 policies increased the subway ridership by about $24 \%$. However, there could still be hesitations and concerns to use public transit and as shown in [50], passengers, who are anxious and concerned about pandemic information, perceived less safety on public transport. In addition to such policies, additional payments can be provided to the public transport operators to maintain the services [51]. However, these solutions are short-term, and a major rethinking is required to provide persisting solutions.

\section{Methodology}

\subsection{Study Area}

This research study was conducted in Lahore, Pakistan, which is the second most populous city of Pakistan with a population exceeding 11 million people and an area of about 1772 sq. Km. Public transport in the city mainly consists of conventional buses and bus rapid transit (metrobus) operated by the local government. Recently, an intercity train (orange line metro train) operation has also started along a specific route in Lahore. There are several para-transit modes e.g., auto rickshaw, motorcycle rickshaw (Qingqi), wagons/vans, demand-responsive transport (Airlift/SWVL), and taxi services (conventional taxi, Uber, and Careem etc.). Since Lahore is a major hub for educational, social, and financial activities, its population is increasing due to migration from other areas. The demand for public transport is also rising with the increase in population. The COVID-19 timeline in Pakistan is shown in Figure 1. 


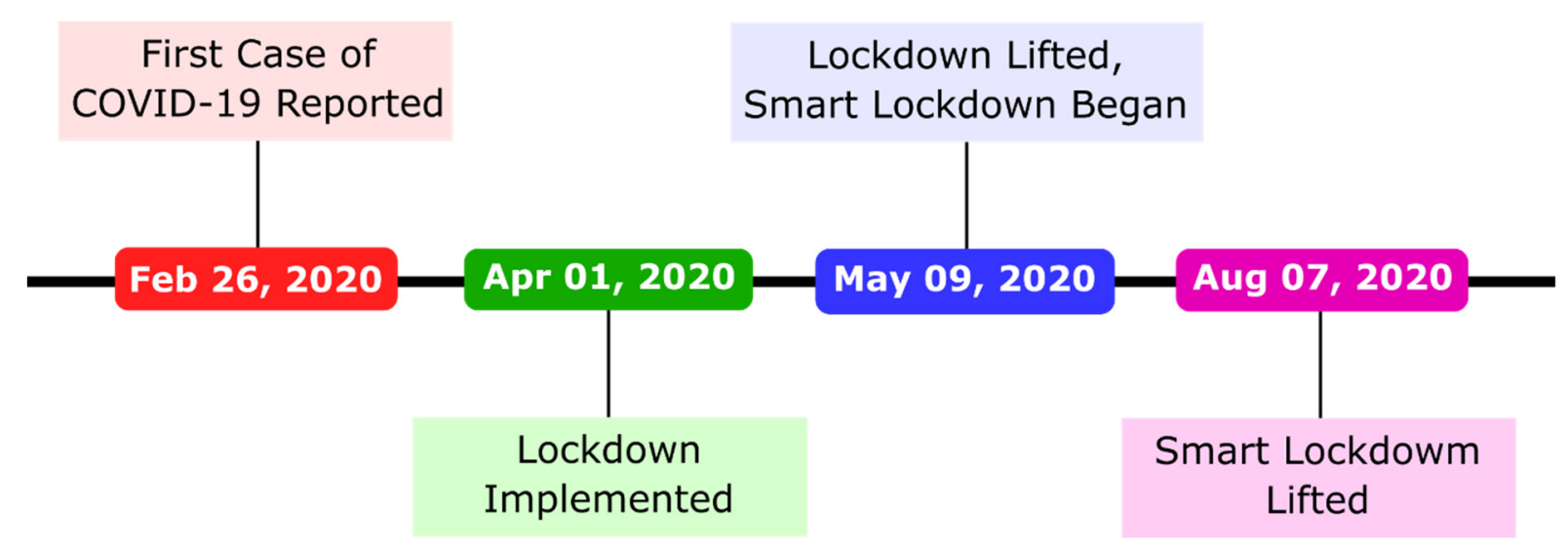

Figure 1. COVID-19 timeline in Pakistan.

\subsection{Questionnaire Survey}

A questionnaire consisting of three different sections was designed. The first section was designed to collect information about socio-economic and -demographic features (SEDs) such as gender, age, income, and car ownership etc. It also contained some questions about travel behavior such as traveling frequency etc. The second section consisted of 5-point Likert-type items about the intentions to use public transport during the pandemic, to adhere to safety instructions, and to use public transport while experiencing the COVID19 symptoms. The third section included carefully designed Likert items to explore the underlying unobservable factor which could affect the intentions to use public transport during the pandemic. An extensive literature review pointed towards three main factors: awareness, the ascription of responsibility, and difficulty. Other items related to attitudes were also added in this section. The Likert items were carefully designed to represent these unobservable factors. The data was collected through personal interviews (face-to-face approach). However, it was made sure that safety guidelines about the spread of the COVID-19 virus are fully observed while conducting the interview surveys. Interviewers were advised and trained to maintain a necessary social distancing, use sanitizers and wear facemasks during the interviews. The face-to-face interview method is generally reliable and has a relatively higher response rate, however, it has certain disadvantages such as interviewer bias, high cost per participant, geographical limitations, and time pressure on respondents. To overcome these issues, well-educated interviewers were hired for data collection purposes who were properly briefed about the study before the commencement of the survey. In addition, the length of the questionnaire was kept reasonable i.e., less than $15 \mathrm{~min}$. The questionnaire did not collect any personal identifying details and all of the respondents were informed about the use of the information collected.

\subsection{Questionnaire Administration and Sample Size}

A convenience-based random sampling strategy was adopted for data collection. A total of 1516 samples were collected from the target respondents using the personal interviews approach. The data was collected during the months of October and November of 2020. A well-educated team of interviewers collected the data. The team was properly briefed about the study and was also instructed to follow the necessary precautions during the interviews. The survey was conducted at important locations in Lahore city such as Racecourse, Qaddafi Stadium, Liberty Market, Mughalpura Railway Station, Anarkali, Mall road, and various bus stations.

\subsection{Data Analyses Methods}

Initially, a descriptive analysis of the collected data was carried out (Table 1). The questionnaire included several items which affect public transport use during the pandemic. Many of these items measured a single underlying factor. Exploratory factor analysis is one 
such technique which can be used to extract those underlying factors. Hence, exploratory factor analysis (EFA) was conducted on the items affecting public transport use during the COVID-19 pandemic. The underlying factors were extracted using the maximum likelihood method. Orthogonal Varimax rotation was employed to obtain interpretable underlying factors. For further statistical analyses, factor scores were computed for each participant using regression approach to represent its relative standing on the underlying factors. Three different regression models were then developed to model the intentions of the users to use public transport during the pandemic, to follow safety precautions and to use public transport while having the COVID-19 symptoms (Figure 2). SEDs and the underlying factors were entered as the explanatory variables in all three models. $p$ values of 0.05 were used to indicate statistically significant variables which imply $95 \%$ confidence level. The statistical software package SPSS v. 20 was used for the statistical analyses. The flow of the study is described in Figure 3.

Table 1. Scio-economic and -demographic characteristics (SEDs) of the respondents.

\begin{tabular}{ll}
\hline \multicolumn{1}{c}{ Characteristics } & \multicolumn{1}{c}{ Distribution (\%) } \\
\hline Gender & Male (65.5), female (34.5) \\
Age (years) & Under 20 (11.9), 20-30 (48.3), 31-40 (30.8), 41-50 (7.5), above \\
Marital status & $50(1.5)$ \\
Education & Single (56.7), married (43.3) \\
& High school (13.3), higher secondary school (14.8), bachelor \\
Profession & (45.5), master and above (26.5) \\
& Students (22.8), civil employees (27.3), private employees \\
Household income (PKR) & (35.2), others (14.8) \\
Car ownership & Under 30,000 (14.7), 30,000-60,000 (33.3), 61,000-100,000 (31.5), \\
Motorcycle ownership & more than 60,000 (20.5) \\
Trip frequency & Yes (37.6), No (62.4) \\
& Yes (61.8), No (38.2) \\
& $1-2$ days a week (11.8), 3-4 days a week (18.7), 5-6 days a \\
& week (43.2), almost every day a week (26.3)
\end{tabular}

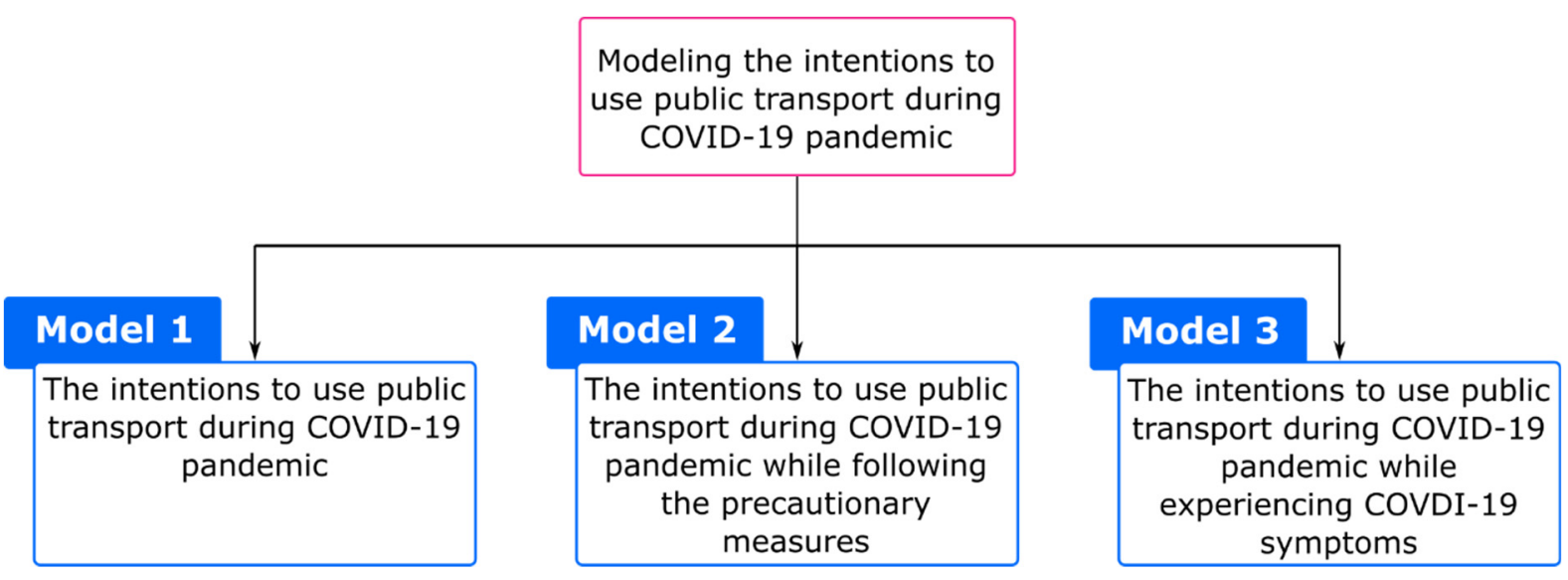

Figure 2. Description of the models developed in this study. 


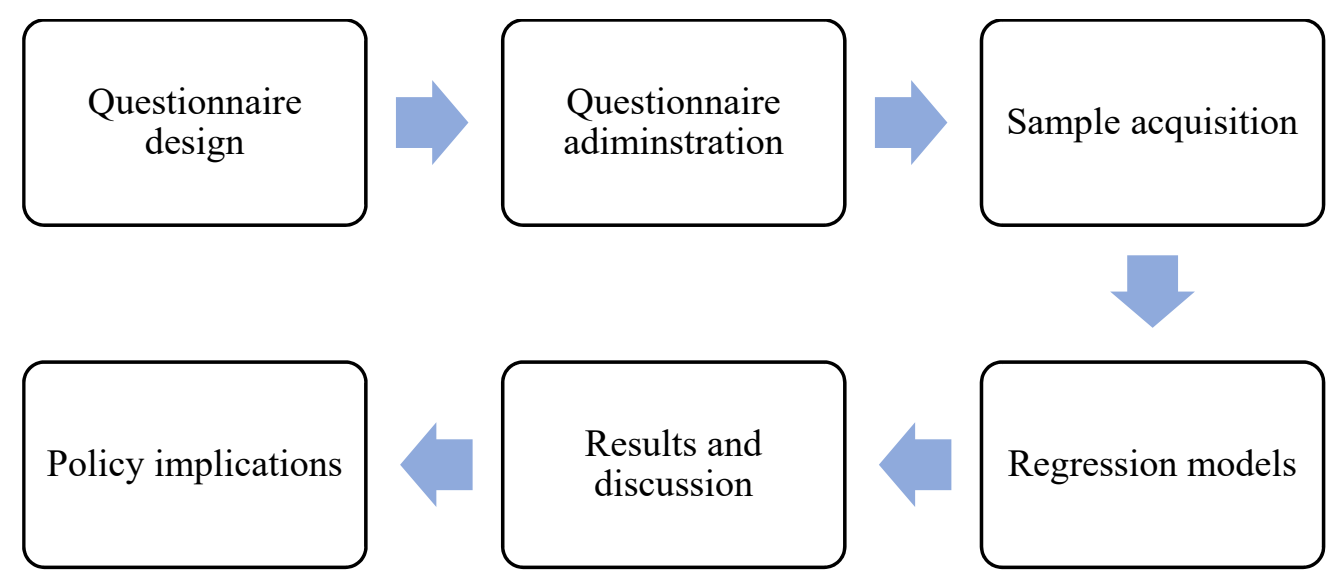

Figure 3. Research methodology adopted for the study.

\section{Results and Discussion}

\subsection{Descriptive Analysis}

The descriptive statistics of the socio-economic and -demographic characteristics of the respondents are shown in Table 1. The percentage of male respondents is more than female respondents, which is consistent with the share of males and females in the working population in Lahore, Pakistan. The sample is skewed towards younger (20-40 years old) and highly educated class (bachelors and above). Approximately $70 \%$ of the respondents have a trip frequency of 5 or more days a week. The distribution of responses for the items in Section 2 of the questionnaire is shown in Figure 4. It can be seen that most of the respondents (94.2\%) declared that they will use public transport less frequently if they are experiencing COVID-19 symptoms.

Never Rarely Sometimes Often Always

1. How often would you use public transport considering the COVID-19 situation?

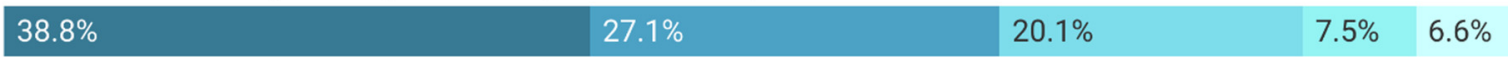

2. How often would you use public transport while you have to maintain a social distance?

\begin{tabular}{|c|c|c|c|}
\hline $31.6 \%$ & $34.9 \%$ & $18.1 \%$ & $12.3 \%$ \\
\hline
\end{tabular}

3. How often would you use public transport while you have to wear a facemask?

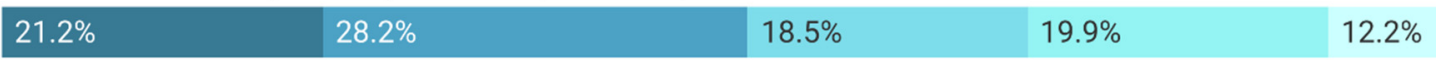

4. How often would you use public transport while you have to use hand sanitizers or disinfectants?

\begin{tabular}{|c|c|c|c|}
\hline $25.1 \%$ & $32.3 \%$ & $17.3 \%$ & $15.2 \%$ \\
\hline
\end{tabular}

5. How often would you use public transport while you have covid-19 symptoms?

$\begin{array}{ll}75.9 \% & 18.3 \%\end{array}$

Figure 4. Distribution of responses for Section 2 of the questionnaire.

\subsection{Exploratory Factor Analysis (EFA)}

Exploratory factor analysis (with maximum likelihood estimation and varimax rotation) was conducted on unobservable factors (the items in Section 3 of the questionnaire) affecting public transport use during the pandemic. A four-factor solution was obtained based on eigenvalues $>1$ criterion which explained about $64.438 \%$ of the total variance. The factor loadings are presented in Table 2. The items with loadings below 0.5 and those with high cross-loadings were removed. The sampling adequacy was satisfactory (Kaiser- 
Meyer-Olkin measure $=0.857$ ); Bartlett's test of sphericity was significant $(0.000)$; and the determinant of the matrix was $1.12 \times 10^{-5}$.

Table 2. Exploratory factor analysis of the questionnaire items (Varimax rotation).

\begin{tabular}{|c|c|c|c|c|}
\hline & Attitudes & Awareness & Responsibility & Difficulty \\
\hline $\begin{array}{l}\text { I would consider public transport for travelling if all } \\
\text { passengers are aware to maintain a social distance. }\end{array}$ & 0.885 & & & \\
\hline $\begin{array}{l}\text { I will only use public transport when vehicles are } \\
\text { properly disinfected. }\end{array}$ & 0.839 & & & \\
\hline $\begin{array}{l}\text { I would consider public transport for travelling if all } \\
\text { related facilities are properly disinfected. }\end{array}$ & 0.790 & & & \\
\hline $\begin{array}{l}\text { I will only use public transport when COVID-19 } \\
\text { related safety guidelines are fully followed. }\end{array}$ & 0.776 & & & \\
\hline $\begin{array}{l}\text { I would consider public transport for travelling if all } \\
\text { passengers wear a facemask. }\end{array}$ & 0.734 & & & \\
\hline $\begin{array}{l}\text { I would consider public transport for travelling if the } \\
\text { vehicles are uncongested. }\end{array}$ & 0.731 & & & \\
\hline $\begin{array}{l}\text { I do/would avoid using public transport as I have a } \\
\text { fear of being infected. }\end{array}$ & 0.540 & & & \\
\hline $\begin{array}{l}\text { I believe that wearing a face mask protects us from } \\
\text { COVID-19 while travelling on public transport. }\end{array}$ & & 0.847 & & \\
\hline $\begin{array}{l}\text { I believe that maintaining a social distance helps in } \\
\text { avoiding COVID-19 infection while travelling on } \\
\text { public transport. }\end{array}$ & & 0.825 & & \\
\hline $\begin{array}{l}\text { I believe that the use of hand sanitizers or } \\
\text { disinfectants can prevent us from COVID-19 infection } \\
\text { while travelling on public transport. }\end{array}$ & & 0.641 & & \\
\hline $\begin{array}{l}\text { I believe that avoid travelling with COVID-19 } \\
\text { symptoms can reduce the spread of disease. }\end{array}$ & & 0.619 & & \\
\hline $\begin{array}{l}\text { I feel a moral obligation to wear a facemask while } \\
\text { travelling on public transport. }\end{array}$ & & 0.597 & & \\
\hline $\begin{array}{l}\text { I feel a moral obligation to avoid travelling on public } \\
\text { transport if I have COVID-19 symptoms. }\end{array}$ & & 0.556 & & \\
\hline $\begin{array}{l}\text { I feel an equal responsibility to use sanitizers for the } \\
\text { safety of all passengers. }\end{array}$ & & & 0.879 & \\
\hline $\begin{array}{l}\text { I feel an equal responsibility to keep a social distance } \\
\text { from passengers while travelling on public transport. }\end{array}$ & & & 0.728 & \\
\hline $\begin{array}{l}\text { It is difficult to use hand sanitizers all the time while } \\
\text { travelling on public transport. }\end{array}$ & & & & 0.862 \\
\hline $\begin{array}{l}\text { It is difficult to wear a facemask all the time while } \\
\text { travelling on public transport. }\end{array}$ & & & & 0.768 \\
\hline$\%$ of variance explained & 260.397 & 190.189 & 90.928 & 80.924 \\
\hline Cronbach's alpha & 0.888 & 0.871 & 0.859 & 0.818 \\
\hline
\end{tabular}

The first factor explained $26.397 \%$ of the total variance. Seven items representing attitudes loaded on the first factor, which explained $26.397 \%$ of the total variance and was consequently named as "attitudes". The second factor explained $19.189 \%$ of the total variance and six items loaded on this axis which represented "awareness" of the consequences. The third factor explained $9.928 \%$ of the total variance with two items loading on it representing the responsibility to keep public transport safe during the pandemic. Therefore, this factor was referred to as "responsibility". The fourth factor explained $8.924 \%$ of the total variance. Two items loaded on this factor which represented the "difficulty" in following precautionary guidelines while using public transport during the pandemic. Cronbach's alpha was adequate for all the factors i.e., $0.888,0.871,0.859$ and 0.818 , respectively suggesting that the items have high internal consistency.

Three different models were developed treating the items in the Section 2 of the questionnaire as dependent variables and those in Sections 1 and 3 as explanatory variables (Figure 1).

\subsection{Model 1-Intentions to Use Public Transport during COVID-19 Pandemic}

An ordinal regression model was developed to model the intentions to use public transport during the COVID-19 pandemic. Socio-economic and -demographic variables, and the underlying factors were entered as the explanatory variables. Correlations were 
checked before entering the explanatory variables. Income was removed from the explanatory variables since it had a strong correlation with age. Item 1 of Section 2 of the questionnaire (How often would you use public transport considering the COVID-19 pandemic) was entered as the dependent variable. Since the distribution of responses was skewed towards "never" as compared to "always", the five levels (never to always) were collapsed into three levels as "never-rarely", "sometimes", and "often—always". The chi-square statistic was significant indicating that the model is a significant improvement over the intercept-only model (Table 3). However, the goodness-of-fit measures i.e., Pearson statistic and Deviance statistic were significant which could be attributed to the fact that there were zero frequencies in a considerable number of cells especially because of the continuous predictors and these statistics may not provide stable estimates of goodness-of-fit under such conditions [52]. The good-of-fit measures i.e., Cox and Snell, Nagelkerke, and McFadden pseudo R square were 0.203, 0.246 and 0.130 , respectively. The non-significant chi-square statistic $\left(\chi^{2}=4.946, \mathrm{df}=19, p=0.999\right)$ indicated that the test of parallel lines was satisfied. Parameter estimates for the ordinal regression model are shown in Table 4 . The sign of the coefficients indicates direct or indirect relationships between continuous explanatory variables and the ordinal outcome variable. The relative values of the coefficients for factor categories can help in explaining the effects of the categorical explanatory variables. The sign of a coefficient for a factor category indicates the effect of a particular factor category relative to the reference category. Age, profession, car ownership, motorbike ownership, education and the four underlying factors were found to be significant explanatory variables (i.e., $p$-values $<0.05$ ). The signs of the coefficients indicate that the underlying factors, "attitudes", "responsibility" and "difficulty" had an inverse relationship whereas, "awareness" had a direct relationship with the intentions to use public transport during the pandemic. It means that those with higher awareness about the disease and its transmission may use public transport more frequently during the pandemic. Whereas, those who consider it to be their responsibility to take precautionary measures may avoid the use of public transport altogether to promote self-isolation. Similarly, those experiencing difficulties while following the necessary precautions may also reduce the use of public transport during the pandemic. The value of coefficients for [marital status = single] is positive (0.081), which suggests that singles are more likely to use public transport as compared to married people during the pandemic. Similarly, the coefficients for various categories (31-40 and 41-50 years) of age indicated that those in the younger age groups are more likely to use public transport during the pandemic relative to those in the oldest age category (i.e., above 50). It could be attributed to the fact that the virus has been found to be particularly dangerous for older people and therefore, they may use public transport less frequently during the pandemic [53]. Students and government and public employees are more likely to use public transport during the pandemic relative to others which may include housewives and retired personnel. In addition, government and public employee are more likely to use public transport during the pandemic relative to students. It can be explained by the fact that educational institutions were closed in Lahore during the pandemic. Car owners and motorbike owners are less likely to use public transport relative to non-car owners and non-motorbike owners. Since the virus spreads through close contact with other people and infected surfaces causing public transport to be more risky, private cars and motorbike offer alternative travel choices with lower chances of infection. The positive coefficients for all the categories of education variable indicate that those with lower educational qualifications are more likely to use public transport during the pandemic. The descriptive analysis showed that those with lower educational qualifications have lower household income and are less likely to own a private car or a motorbike making them captive public transport user. 
Table 3. Model 1-Model fitting information.

\begin{tabular}{lcccc}
\hline Model & $\begin{array}{c}-\mathbf{2} \text { Log } \\
\text { Likelihood }\end{array}$ & Chi-Square & df & Sig. \\
\hline $\begin{array}{l}\text { Intercept Only } \\
\text { Final }\end{array}$ & 2639.734 & 343.779 & 19 & 0.000 \\
\hline Link function: Logit. & 2295.955 & &
\end{tabular}

Table 4. Model 1-Parameter estimates for the ordinal regression model.

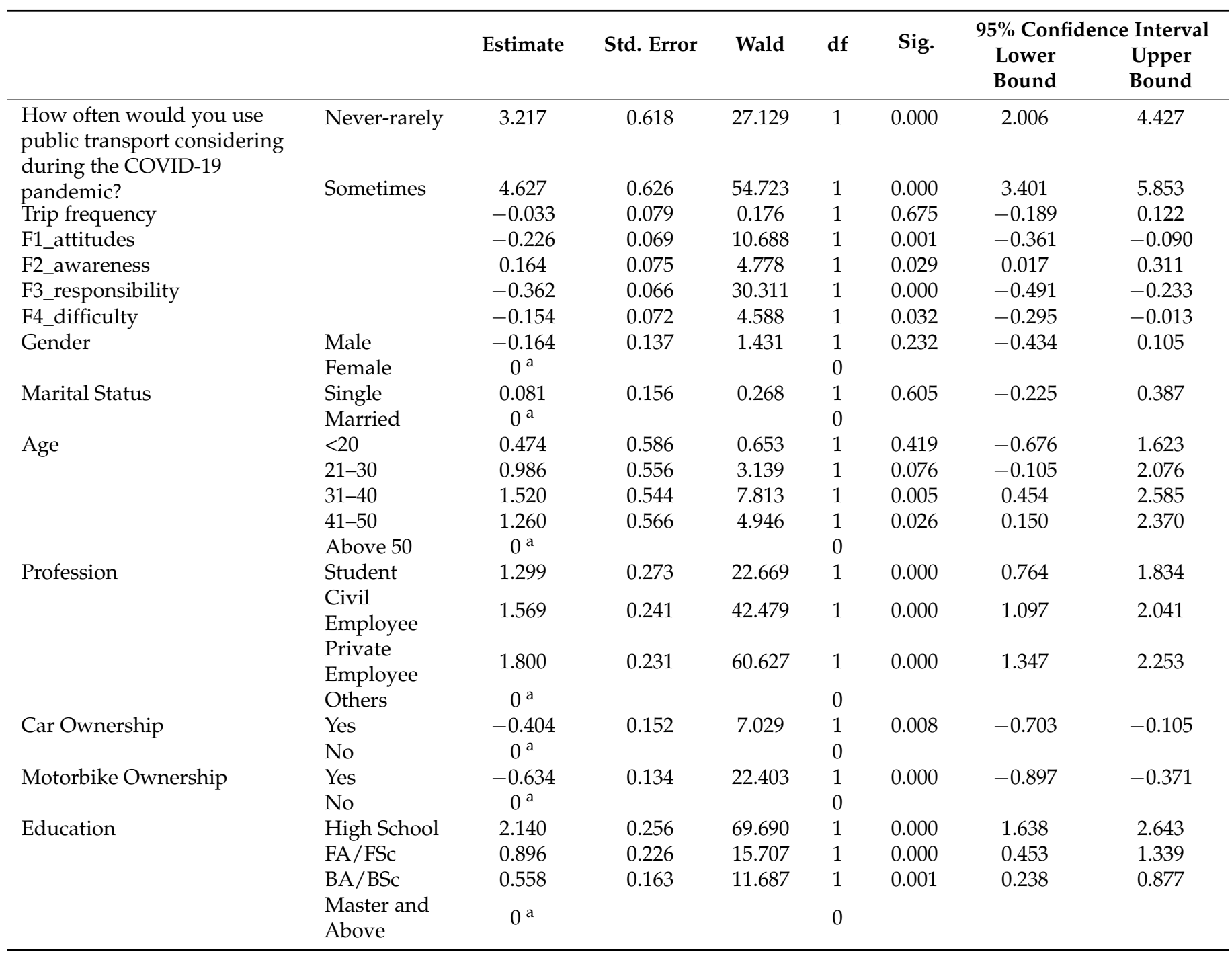

Link function: Logit. Reference category: Often-always. ${ }^{\text {a }}$ This parameter is set to zero because it is redundant.

4.4. Model 2-Intentions to Use Public Transport during COVID-19 Pandemic While Adhering to Safety Precautions

The items 3 to 4 of Section 2 of the questionnaire (How often would you use public transport while you have to maintain a social distance? How often would you use public transport while you have to wear a facemask? and How often would you use public transport while you have to use hand sanitizers or disinfectants?) represent the intentions to adhere to safety precautions while using public transport during COVID-19 pandemic. A single factor underlying these items was extracted using exploratory factor analysis and the corresponding regression factor scores were computed (Table 5). A multiple linear regression model was then developed by treating the underlying factor as a dependent variable. SEDs and the underlying factors namely, attitudes, awareness, responsibility, 
and difficulty were entered as explanatory variables. The F-ratio tests indicate that the explanatory variables are statistically significant in explaining the outcome variable, $\mathrm{F}$ $(12,1477)=19.385, p<0.0005$ (i.e., the regression model is a good fit of the data). The Rsquared and adjusted R-squared values are 0.136 and 0.129 , respectively. The relatively low R-squared values indicate that there may be other variables affecting the intentions to use public transport during the COVID-19 pandemic. Certain possible factors might include governmental lockdowns and shift to online work etc. The model has low prediction power; however, it is significant and useful for explanatory purposes. Gender, car ownership, motorbike ownership, trip frequency, age, education, and the underlying factors "attitudes", "responsibility" and "difficulty" were found to be significant explanatory variables (i.e., $p$-values < 0.05). The positive coefficient for gender indicated that females are more likely to use public transport during the pandemic while they have to adhere to safety precautions. Existing literature suggests that females have higher risk perception of the COVID-19 pandemic [54] and therefore, may be likely to follow the necessary precautions while using public transport. The positive coefficients for car ownership and motorbike ownership indicated that those who do not own a car and motorbike are more likely to use public transport while they have to adhere to safety precautions. Since the users without a private car or a motorbike can be classified as captive users, they do not have an option other than using public transport while following the necessary precautions. Those belonging to higher age are more likely to public transport while they have to follow the safety guidelines including wearing a face mask, using hand sanitizer and maintaining a social distance. Those who find it difficult to follow the necessary precautions are less likely to use public transport during the pandemic while they have to follow the precautionary measures. Furthermore, those who believe that they are responsible for their actions are more likely to use public transport while following the necessary precautions.

Table 5. Model 2-Parameter estimates for the multiple linear regression model.

\begin{tabular}{|c|c|c|c|c|c|}
\hline \multirow[t]{2}{*}{ Model } & \multicolumn{2}{|c|}{$\begin{array}{l}\text { Unstandardized } \\
\text { Coefficients }\end{array}$} & \multirow{2}{*}{$\begin{array}{c}\text { Standardized } \\
\text { Coefficients } \\
\text { Beta }\end{array}$} & \multirow[t]{2}{*}{$\mathbf{t}$} & \multirow[t]{2}{*}{ Sig. } \\
\hline & B & Std. Error & & & \\
\hline (Constant) & -0.654 & 0.213 & & -3.068 & 0.002 \\
\hline Gender & 0.197 & 0.054 & 0.098 & 3.615 & 0.000 \\
\hline Marital Status & -0.093 & 0.061 & -0.048 & -1.529 & 0.126 \\
\hline Profession & -0.014 & 0.027 & -0.015 & -0.524 & 0.600 \\
\hline Car Ownership & 0.316 & 0.056 & 0.159 & 5.598 & 0.000 \\
\hline Motorcycle Ownership & 0.244 & 0.052 & 0.123 & 4.655 & 0.000 \\
\hline Trip Frequency & -0.098 & 0.027 & -0.097 & -3.598 & 0.000 \\
\hline F1_attitudes & 0.170 & 0.027 & 0.167 & 6.361 & 0.000 \\
\hline F2_awareness & 0.022 & 0.026 & 0.021 & 0.832 & 0.406 \\
\hline F3_responsibility & 0.092 & 0.026 & 0.090 & 3.538 & 0.000 \\
\hline F4_difficulty & -0.140 & 0.027 & -0.132 & -5.195 & 0.000 \\
\hline Age & 0.089 & 0.042 & 0.073 & 2.122 & 0.034 \\
\hline Education & -0.079 & 0.029 & -0.078 & -2.694 & 0.007 \\
\hline
\end{tabular}

Dependent Variable: REGR factor score.

\subsection{Model 3-Intentions to Use Public Transport during COVID-19 Pandemic While Experiencing the COVID-19 Symptoms}

An ordinal regression model was developed to model the intentions to use public transport during COVID-19 pandemic while experiencing the COVID-19 symptoms. Socioeconomic and -demographic variables, and the underlying factors were entered as the explanatory variables. Income was removed from the model since it had a strong correlation with age. Item 5 of Section 2 of the questionnaire (How often would you use public transport while you have covid-19 symptoms?) was entered as the dependent variable. The chi-square statistic was significant $\left(\chi^{2}=297.205, \mathrm{df}=19, p<0.005\right)$ indicating that the model is a significant improvement over the intercept-only model (Table 6). Deviance statistic was significant $\left(\chi^{2}=1880.049, \mathrm{df}=2901, p=1.000\right)$. However, Pearson statistic was 
non-significant $\left(\chi^{2}=9792.048, \mathrm{df}=2901, p<0.05\right)$. The good-of-fit measures i.e., Cox and Snell, Nagelkerke, and McFadden pseudo-R square were $0.178,0.233$ and 0.136 , respectively. The non-significant chi-square statistic $\left(\chi^{2}=67.794, \mathrm{df}=57, p=0.155\right)$ indicated that the test of parallel lines was satisfied. Trip frequency, marital status, age, profession and education were found to be significant explanatory variables (Table 7). More frequent travelers are less likely to use public transport while they have COVID-19 symptoms. Singles are less likely to use public transport relative to married people when they have COVID-19 symptoms. Those in the younger age groups are more likely to use public transport while experiencing COVID-19 symptoms relative to those in the oldest age group, which could be explained by the fact that the disease proved to be particularly dangerous for older people. Those with low educational qualifications are more likely to use public transport while experiencing COVID-19 relative to those having higher qualifications. As explained earlier, the respondents with lower educational qualifications had lower household incomes and lower car and motorbike ownerships making them captive public transport users.

Table 6. Model 3-Model fitting information.

\begin{tabular}{ccccc}
\hline Model & $-\mathbf{2}$ Log Likelihood & Chi-Square & df & Sig. \\
\hline $\begin{array}{c}\text { Intercept Only } \\
\text { Final }\end{array}$ & 2180.824 & & & \\
\hline Link function: Logit & 1883.619 & 297.205 & 19 & 0.000 \\
\hline
\end{tabular}

Link function: Logit.

Table 7. Model 3-Parameter estimates for the ordinal regression model.

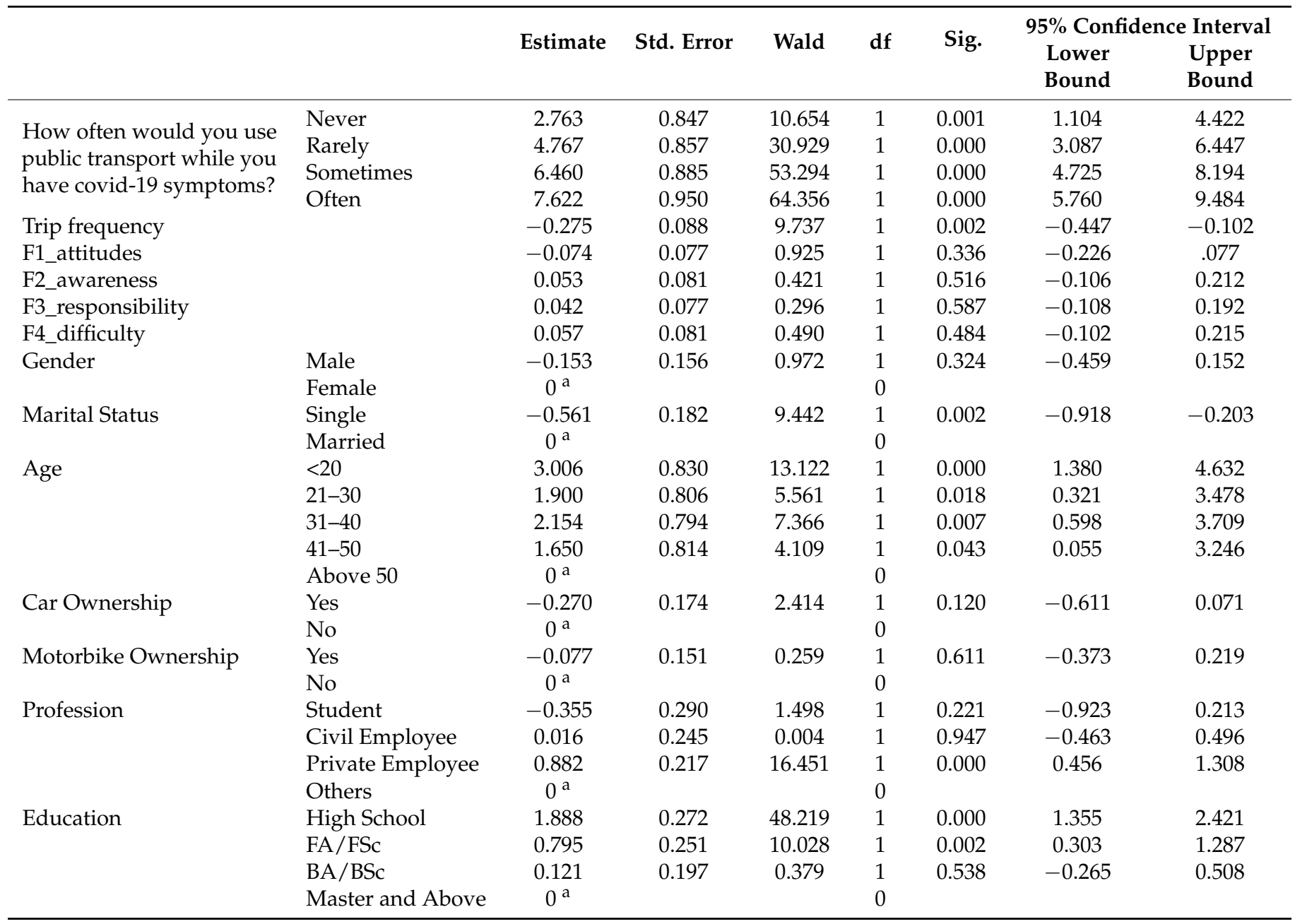




\section{Policy Implications}

During the COVID-19 pandemic, people reduce the use of public transport due to the perceived fear of infection. On the other hand, operators tend to reduce their services due to the declined demand and profits. Regaining trust in public transport modes is important, particularly in developing countries, while maintaining necessary safety levels. This might be achieved through various demand management techniques, e.g., controlling demands and queues, time and space dependent pricing, advance reservation and booking schemes, etc. [55]. However, such schemes have direct links to existing public transport means and therefore, some intervention by government authorities might be needed. Therefore, the possibility of deploying other flexible alternatives, e.g., demand responsive transport, para transits, should be explored to satisfy the travel needs of people.

The difficulty in using hand sanitizers and wearing face masks all the time in public transport was negatively associated with public transport use when the users have to follow the necessary precautions. Alternative options such as maintaining social distance by leaving certain seats vacant in the public transport and properly ventilating and disinfecting the public transport may also be exercised. This may require training for public transport drivers. The results also indicated that awareness and the ascription of responsibility had no significant effect on public transport use while experiencing COVID-19 symptoms. More effective campaigns about the consequences of the disease spread may increase the awareness and responsibility among the public transport users. Removeable stickers or variable message signs in the vehicles should be placed mentioning the guidelines of safety and to increase the awareness among travelers. Furthermore, people with low educational qualifications are more likely to use public transport during the pandemic, however, they are less likely to use it if they have to follow the necessary precautions. Hence, public transport users with low educational qualifications and low household incomes should be specifically targeted in such campaigns. In addition, free masks and hand sanitizers in public transport vehicles may prove helpful in attracting this particular segment of the society back to public transport. Local governments may provide incentives to the public transport operators for arranging these requisites to curb the spread of the virus in public transport systems. The models developed in this study suggest that certain segments of the society may reduce the use of public transport due to either the pandemic, the necessity to follow the precautionary measures or the COVID-19 symptoms.

Past evidence suggests that public transport use declined during the pandemic [42], which has disrupted public transport operations around the world. Hence, alternative traveling options for lower public transport demand such as demand-responsive-transport (DRT) coupled with necessary precautions should also be explored to cater the existing public transport demand. Ref. [56] reported that the demand for DRT was almost unaffected by the pandemic. Since several smartphone application-based DRT services are more flexible in their operation and can keep a track record of their passengers. In addition, most of these services are use mobile applications for registering users demand and collecting fare [57]. Hence, they have the potential advantage of managing their demand more effectively while minimizing the virus transmission. Operators of these public transport DRT services should adapt to the new normal to sustain their operations during the COVID-19 pandemic. For example, regardless the size of the vehicle, the DRT services may need to reduce their seating capacity to ensure social distancing. Further, extended services, i.e., door-to-door services, could also be provided as there is a possibility to use flexible routes in contrast to traditional fixed-route public transport systems. Effective coordination between all the stakeholders including government authorities and public transport/DRT operators may prove helpful in regaining the trust of the users during the pandemic. Private partnerships and sponsorships may also help public transport/DRT services in reviving their operations. 


\section{Conclusions}

Three different models were developed in this study to explore people's intentions to use public transport during the pandemic, to use public transport while following the necessary precautions, and to use public transport while experiencing the COVID-19 symptoms. The data was collected through a questionnaire survey conducted in Lahore, Pakistan. The results indicated that older people are less likely to use public transport during the pandemic, however, they are more likely to use public transport when they have to follow the necessary precautions. In addition, older people declared less often public transport use when they have COVID-19 symptoms. People with low educational qualifications are more likely to use public transport during the pandemic, however, they are less likely to use it if they have to follow the necessary precautions. Furthermore, people with low educational qualifications are more likely to use public transport while experiencing COVID-19 symptoms. The underlying factors "attitudes", "responsibility" and "difficulty" had an inverse relationship whereas, "awareness" had a direct relationship with the intentions to use public transport during the pandemic. The underlying factor, "difficulty", was found to be associated with less often public transport use while the users have to follow the necessary precautions. This means that these underlying factors play a key role in determining the choice of public transport and intention to use public transport during the pandemic and post-pandemic times. Outcomes of this study help in understanding the intentions of the public transport users during the COVID-19 pandemic. Necessary precautions should be exercised while transferring the results of this study to other countries especially developed countries since they may have different travel modes as compared to developing countries. Nonetheless, the study provides important insights for policymakers and public transport operators for planning safe public transport operations during the current and any possible future pandemics.

This study had some limitations. The sample was skewed towards the younger and more educated population. In order to better analyze the behavioral component of public transport travelers, future research steps will focus on a broader sampling and assessment of feelings of fear, anxiety and stress generated by the use of public transport during different pandemic periods. In addition, studies with repeated measurement design can also be conducted since people may adapt to the pandemic and as a result, may perceive it to be less risky. Furthermore, a cross-country comparison may also provide further insights into public transport use during pandemics. Also, the factors causing non-compliance to precautionary measures especially while using public transport should also be studied.

Author Contributions: Conceptualization, M.A., N.A., M.A.J. and C.D.; methodology, M.A., and C.D.; data collection, N.A., M.A.J. and M.A.; data analysis, M.A. and C.D.; writing- original draft preparation, M.A., N.A., C.D., T.C. and M.A.J.; writing-review and editing, M.A., N.A., C.D., T.C. and M.A.J.; funding, T.C. All authors have read and agreed to the published version of the manuscript.

Funding: The authors acknowledge partial financial support from the MIUR (Ministry of Education, Universities and Research [Italy]) through a project entitled WEAKI TRANSIT: WEAK-demand areas Innovative Transport Shared services for Italian Towns (Project code: 20174ARRHT/CUP Code: J74I19000320008), financed with the PRIN 2017 (Research Projects of National Relevance) program. We authorize the MIUR to reproduce and distribute reprints for Governmental purposes, notwithstanding any copyright notations thereon. Any opinions, findings, and conclusions or recommendations expressed in this material are those of the authors and do not necessarily reflect the views of the MIUR.

Institutional Review Board Statement: Not applicable.

Informed Consent Statement: Informed consent was obtained from all subjects involved in the study.

Data Availability Statement: The data presented in this study are available on request from the corresponding authors. The data are not publicly available because certain measures are still need to be used in other studies. 
Conflicts of Interest: The authors declare no conflict of interest.

\section{References}

1. WHO. Coronavirus Disease (COVID-19) Pandemic. 2020. Available online: https://www.who.int/emergencies/diseases/novelcoronavirus-2019 (accessed on 21 February 2021).

2. COVID-19 Health Advisory Platform by Ministry of National Health Services Regulations and Coordination. Available online: http:/ / covid.gov.pk/ (accessed on 21 February 2021).

3. Gutiérrez, A.; Miravet, D.; Domènech, A. COVID-19 and urban public transport services: Emerging challenges and research agenda. Cities Health 2020, 1-4. [CrossRef]

4. Pawar, D.S.; Yadav, A.K.; Akolekar, N.; Velaga, N.R. Impact of physical distancing due to novel coronavirus (SARS-CoV-2) on daily travel for work during transition to lockdown. Transp. Res. Interdiscip. Perspect. 2020, 7, 100203. [CrossRef]

5. Cooley, P.; Brown, S.; Cajka, J.; Chasteen, B.; Ganapathi, L.; Grefenstette, J.; Hollingsworth, C.R.; Lee, B.Y.; Levine, B.; Wheaton, W.D.; et al. The Role of Subway Travel in an Influenza Epidemic: A New York City Simulation. J. Hered. 2011, 88, $982-995$. [CrossRef] [PubMed]

6. Feske, M.L.; Teeter, L.D.; Musser, J.M.; Graviss, E.A. Giving TB wheels: Public transportation as a risk factor for tuberculosis transmission. Tuberculosis 2011, 91, S16-S23. [CrossRef] [PubMed]

7. Troko, J.; Myles, P.; Gibson, J.; Hashim, A.; Enstone, J.; Kingdon, S.; Packham, C.; Amin, S.; Hayward, A.; Van-Tam, J.N. Is public transport a risk factor for acute respiratory infection? BMC Infect. Dis. 2011, 11, 16. [CrossRef] [PubMed]

8. Muley, D.; Shahin; Dias, C.; Abdullah, M. Role of Transport during Outbreak of Infectious Diseases: Evidence from the Past. Sustainability 2020, 12, 7367. [CrossRef]

9. Budd, L.; Ison, S. Responsible Transport: A post-COVID agenda for transport policy and practice. Transp. Res. Interdiscip. Perspect. 2020, 6, 100151. [CrossRef]

10. Liu, X.; Zhang, S. COVID-19: Face masks and human-to-human transmission. Influenza Other Respir. Viruses 2020, 14, 472-473. [CrossRef]

11. Lyu, W.; Wehby, G.L. Community Use of Face Masks and COVID-19: Evidence from a Natural Experiment of State Mandates in the US. Health Aff. 2020, 39, 1419-1425. [CrossRef] [PubMed]

12. Moreno, T.; Pintó, R.M.; Bosch, A.; Moreno, N.; Alastuey, A.; Minguillón, M.C.; Anfruns-Estrada, E.; Guix, S.; Fuentes, C.; Buonanno, G.; et al. Tracing surface and airborne SARS-CoV-2 RNA inside public buses and subway trains. Environ. Int. 2021, 147, 106326. [CrossRef]

13. Howland, R.E.; Cowan, N.R.; Wang, S.S.; Moss, M.L.; Glied, S. Public transportation and transmission of viral respiratory disease: Evidence from influenza deaths in 121 cities in the United States. PLoS ONE 2020, 15, e0242990. [CrossRef] [PubMed]

14. Tirachini, A.; Cats, O. COVID-19 and public transportation: Current assessment, prospects, and research needs. J. Public Transp. 2020, 22, 1. [CrossRef]

15. Dzisi, E.K.J.; Dei, O.A. Adherence to social distancing and wearing of masks within public transportation during the COVID 19 pandemic. Transp. Res. Interdiscip. Perspect. 2020, 7, 100191. [CrossRef]

16. Suman, H.K.; Agarwal, A.; Bolia, N.B. Public Transport Operations after Lockdown: How to Make It Happen? Trans. Indian Natl. Acad. Eng. 2020, 5, 149-156. [CrossRef]

17. Campisi, T.; Basbas, S.; Skoufas, A.; Akgün, N.; Ticali, D.; Tesoriere, G. The Impact of COVID-19 Pandemic on the Resilience of Sustainable Mobility in Sicily. Sustainability 2020, 12, 8829. [CrossRef]

18. Wilson, W.; Raj, J.P.; Rao, S.; Ghiya, M.; Nedungalaparambil, N.M.; Mundra, H.; Mathew, R. Prevalence and Predictors of Stress, anxiety, and Depression among Healthcare Workers Managing COVID-19 Pandemic in India: A Nationwide Observational Study. Indian J. Psychol. Med. 2020, 42, 353-358. [CrossRef] [PubMed]

19. Kassaw, C.; Pandey, D. COVID-19 Pandemic Related to Anxiety Disorder Among Communities Using Public Transport at Addis Ababa, Ethiopia, March 2020: Cross-sectional Study Design. Hum. Arenas 2021, 1-10. [CrossRef]

20. Al-Rashid, M.A.; Goh, H.C.; Harumain, Y.A.S.; Ali, Z.; Campisi, T.; Mahmood, T. Psychosocial Barriers of Public Transport Use and Social Exclusion among Older Adults: Empirical Evidence from Lahore, Pakistan. Int. J. Environ. Res. Public Health 2020, 18, 185. [CrossRef]

21. Tesoriere, G.; Campisi, T. The Benefit of Engage the "Crowd" Encouraging a Bottom-up Approach for Shared Mobility Rating. In Proceedings of the International Conference on Computational Science and Its Applications, Cagliari, Italy, 1-4 July 2020; Springer: Cham, Switzerland, 2020; pp. 836-850.

22. Basu, R.; Ferreira, J. Sustainable mobility in auto-dominated Metro Boston: Challenges and opportunities post-COVID-19. Transp. Policy 2021, 103, 197-210. [CrossRef]

23. Zhang, Y.; Zhang, Y.; Liu, Z. The role of different transportation in the spreading of new pandemic influenza in mainland China. In Proceedings of the 19th International Conference on Geoinformatics, Shanghai, China, 24-26 June 2011; pp. 1-6.

24. Goscé, L.; Johansson, A. Analysing the link between public transport use and airborne transmission: Mobility and contagion in the London underground. Environ. Health 2018, 17, 1-11. [CrossRef]

25. Harris, J.E. The Subways Seeded the Massive Coronavirus Epidemic in New York City. SSRN Electron. J. 2020, w27021. [CrossRef]

26. Cartenì, A.; Di Francesco, L.; Martino, M. How mobility habits influenced the spread of the COVID-19 pandemic: Results from the Italian case study. Sci. Total Environ. 2020, 741, 140489. [CrossRef] [PubMed] 
27. Buja, A.; Paganini, M.; Cocchio, S.; Scioni, M.; Rebba, V.; Baldo, V. Demographic and socio-economic factors, and healthcare resource indicators associated with the rapid spread of COVID-19 in Northern Italy: An ecological study. PLoS ONE 2020, 15, e0244535. [CrossRef] [PubMed]

28. Morawska, L.; Tang, J.W.; Bahnfleth, W.; Bluyssen, P.M.; Boerstra, A.; Buonanno, G.; Cao, J.; Dancer, S.; Floto, A.; Franchimon, F.; et al. How can airborne transmission of COVID-19 indoors be minimised? Environ. Int. 2020, 142, 105832. [CrossRef] [PubMed]

29. Musselwhite, C.; Avineri, E.; Susilo, Y. Editorial JTH 16 -The Coronavirus Disease COVID-19 and implications for transport and health. J. Transp. Health 2020, 16, 100853. [CrossRef]

30. Chu, D.K.; Akl, E.A.; Duda, S.; Solo, K.; Yaacoub, S.; Schünemann, H.J. Physical distancing, face masks, and eye protection to prevent person-to-person transmission of SARS-CoV-2 and COVID-19: A systematic review and meta-analysis. Lancet 2020, 395, 1973-1987. [CrossRef]

31. Shen, J.; Duan, H.; Zhang, B.; Wang, J.; Ji, J.S.; Wang, J.; Pan, L.; Wang, X.; Zhao, K.; Ying, B.; et al. Prevention and control of COVID-19 in public transportation: Experience from China. Environ. Pollut. 2020, 266, 115291. [CrossRef]

32. Kumar, P.; Khani, A.; Lind, E.; Levin, J. Estimation and Mitigation of Epidemic Risk on a Public Transit Route using Automatic Passenger Count Data. Transp. Res. Rec. 2021. [CrossRef]

33. Hensher, D.A. What might Covid-19 mean for mobility as a service (MaaS)? Transp. Rev. 2020, 40, 551-556. [CrossRef]

34. Tian, H.; Liu, Y.; Li, Y.; Wu, C.-H.; Chen, B.; Kraemer, M.U.G.; Li, B.; Cai, J.; Xu, B.; Yang, Q.; et al. An investigation of transmission control measures during the first 50 days of the COVID-19 epidemic in China. Science 2020, 368, 638-642. [CrossRef] [PubMed]

35. Aloi, A.; Alonso, B.; Benavente, J.; Cordera, R.; Echániz, E.; González, F.; Ladisa, C.; Lezama-Romanelli, R.; López-Parra, Á.; Mazzei, V.; et al. Effects of the COVID-19 Lockdown on Urban Mobility: Empirical Evidence from the City of Santander (Spain). Sustainability 2020, 12, 3870. [CrossRef]

36. Jenelius, E.; Cebecauer, M. Impacts of COVID-19 on public transport ridership in Sweden: Analysis of ticket validations, sales and passenger counts. Transp. Res. Interdiscip. Perspect. 2020, 8, 100242.

37. Bucsky, P. Modal share changes due to COVID-19: The case of Budapest. Transp. Res. Interdiscip. Perspect. $2020,8,100141$. [CrossRef]

38. Wielechowski, M.; Czech, K.; Grzęda, Ł. Decline in Mobility: Public Transport in Poland in the time of the COVID-19 Pandemic. Economies 2020, 8, 78. [CrossRef]

39. Kim, C.; Cheon, S.H.; Choi, K.; Joh, C.-H.; Lee, H.-J. Exposure to fear: Changes in travel behavior during MERS outbreak in Seoul. KSCE J. Civ. Eng. 2017, 21, 2888-2895. [CrossRef]

40. Hotle, S.; Murray-Tuite, P.; Singh, K. Influenza risk perception and travel-related health protection behavior in the US: Insights for the aftermath of the COVID-19 outbreak. Transp. Res. Interdiscip. Perspect. 2020, 5, 100127. [CrossRef]

41. Sadique, M.Z.; Edmunds, W.J.; Smith, R.D.; Meerding, W.J.; De Zwart, O.; Brug, J.; Beutels, P. Precautionary Behavior in Response to Perceived Threat of Pandemic Influenza. Emerg. Infect. Dis. 2007, 13, 1307-1313. [CrossRef] [PubMed]

42. Abdullah, M.; Dias, C.; Muley, D.; Shahin, M. Exploring the impacts of COVID-19 on travel behavior and mode preferences. Transp. Res. Interdiscip. Perspect. 2020, 8, 100255. [CrossRef]

43. De Haas, M.; Faber, R.; Hamersma, M. How COVID-19 and the Dutch 'intelligent lockdown' change activities, work and travel behaviour: Evidence from longitudinal data in the Netherlands. Transp. Res. Interdiscip. Perspect. 2020, 6, 100150. [CrossRef]

44. Beck, M.J.; Hensher, D.A. Insights into the impact of COVID-19 on household travel and activities in Australia-The early days under restrictions. Transp. Policy 2020, 96, 76-93. [CrossRef]

45. Przybylowski, A.; Stelmak, S.; Suchanek, M. Mobility Behaviour in View of the Impact of the COVID-19 Pandemic-Public Transport Users in Gdansk Case Study. Sustainability 2021, 13, 364. [CrossRef]

46. Alahdal, H.; Basingab, F.; Alotaibi, R. An analytical study on the awareness, attitude and practice during the COVID-19 pandemic in Riyadh, Saudi Arabia. J. Infect. Public Health 2020, 13, 1446-1452. [CrossRef] [PubMed]

47. Jones, J.; Sullivan, P.S.; Sanchez, T.H.; Guest, J.L.; Hall, E.W.; Luisi, N.; Zlotorzynska, M.; Wilde, G.; Bradley, H.; Siegler, A.J. Similarities and Differences in COVID-19 Awareness, Concern, and Symptoms by Race and Ethnicity in the United States: Cross-Sectional Survey. J. Med. Internet Res. 2020, 22, e20001. [CrossRef] [PubMed]

48. Matovu, J.K.B.; Kabwama, S.N.; Ssekamatte, T.; Ssenkusu, J.; Wanyenze, R.K. COVID-19 Awareness, Adoption of COVID-19 Preventive Measures, and Effects of COVID-19 Lockdown Among Adolescent Boys and Young Men in Kampala, Uganda. J. Community Health 2021, 1-12. [CrossRef]

49. Dai, J.; Liu, Z.; Li, R. Improving the subway attraction for the post-COVID-19 era: The role of fare-free public transport policy. Transp. Policy 2021, 103, 21-30. [CrossRef]

50. Dong, H.; Ma, S.; Jia, N.; Tian, J. Understanding public transport satisfaction in post COVID-19 pandemic. Transp. Policy 2021, 101, 81-88. [CrossRef]

51. Vickerman, R. Will Covid-19 put the public back in public transport? A UK perspective. Transp. Policy 2021, 103, 95-102. [CrossRef] [PubMed]

52. Smith, T.J.; McKenna, C.M. An examination of ordinal regression goodness-of-fit indices under varied sample conditions and link functions. Mult. Linear Regres. Viewp. 2012, 38, 1-7.

53. Jones, J.H.; Salathé, M. Early Assessment of Anxiety and Behavioral Response to Novel Swine-Origin Influenza A(H1N1). PLoS ONE 2009, 4, e8032. [CrossRef] 
54. Neuburger, L.; Egger, R. Travel risk perception and travel behaviour during the COVID-19 pandemic 2020: A case study of the DACH region. Curr. Issues Tour. 2021, 24, 1003-1016. [CrossRef]

55. Hörcher, D.; Singh, R.; Graham, D.J. Social Distancing in Public Transport: Mobilising New Technologies for Demand Management under the COVID-19 Crisis. SSRN Electron. J. 2020. [CrossRef]

56. Ahangari, S.; Chavis, C.; Jeihani, M. Public Transit Ridership Analysis during the COVID-19 Pandemic. medRxiv 2020. [CrossRef]

57. Abdullah, M.; Ali, N.; Shah, S.; Javid, M.; Campisi, T. Service Quality Assessment of App-Based Demand-Responsive Public Transit Services in Lahore, Pakistan. Appl. Sci. 2021, 11, 1911. [CrossRef] 